\title{
Additional finds of Anthracoidea melanostachyae (Anthracoideaceae)
}

\section{Teodor T. Denchev ${ }^{1 *}$, Cvetomir M. Denchev ${ }^{1}$, Igor V. Karatygin ${ }^{2} \&$ Ernst Vitek ${ }^{3}$}

${ }^{1}$ Institute of Biodiversity and Ecosystem Research, Bulgarian Academy of Sciences, 2 Gagarin St., 1113 Sofia, Bulgaria

${ }^{2}$ Komarov Botanical Institute, Russian Academy of Sciences, 2 Prof. Popov St., 197376 St Petersburg, Russia

${ }^{3}$ Naturhistorisches Museum Wien, Botanische Abteilung, Burgring 7, 1010 Wien, Austria

Received 25 April 2016 / Accepted 11 May 2016 / Published 23 May 2016

Denchev, T.T., Denchev, C.M., Karatygin, I.V. \& Vitek, E. 2016. Additional finds of Anthracoidea melanostachyae (Anthracoideaceae). - Mycobiota 6: 39-45. doi: 10.12664/mycobiota.2016.06.04

Abstract. Anthracoidea melanostachyae, previously known from Iran and Tajikistan on Carex melanostachya, is reported from Armenia and Azerbaijan on the same host plant, and from a new Tajik locality, on a new host plant, $C$. songorica.

Key words: Anthracoidea melanostachyae, Anthracoideaceae, Armenia, Asia, Azerbaijan, Carex melanostachya, Carex songorica, Cyperaceae, Iran, smut fungi, Tajikistan, taxonomy

\section{Introduction}

Anthracoidea melanostachyae was described by Denchev \& Denchev (2011) for accommodation of an ovariicolous smut fungus on Carex melanostachya from Iran and Tajikistan. Additional Iranian specimens of this fungus on the same host plant were reported by Vánky \& Abbasi (2013). Examination of Carex specimens in the herbaria of the Natural History Museum Vienna (W), the Royal Botanic Garden Edinburgh (E), and the Komarov Botanical Institute, Saint Petersburg (LE) revealed new localities of this smut fungus.

Anthracoidea melanostachyae is reported here for the first time from Armenia and Azerbaijan. Additionally, it is recorded from Tajikistan on a second host plant, Carex songorica.

\footnotetext{
*Corresponding author: e-mail: ttdenchev@gmail.com
} 


\section{Material and methods}

Dried specimens of smut fungi from the herbaria of the Natural History Museum Vienna (W), the Royal Botanic Garden Edinburgh (E), and the Komarov Botanical Institute (LE) were examined with a light microscope (LM) and scanning electron microscope (SEM). For LM observations and measurements, spores were mounted in lactoglycerol solution ( $\mathrm{w}: \mathrm{la}: \mathrm{gl}=1: 1: 2$ ) on glass slides, gently heated to boiling point to rehydrate the spores, and then cooled. The measurements of spores are given as min-max (mean \pm 1 standard deviation). For SEM, spores were attached to specimen holders by doublesided adhesive tape and coated with platinum (JEOL JSM 6610-LV) or gold (JEOL JSM-6390) in an ion sputter. The surface structure of the spores was observed and photographed at $10 \mathrm{kV}$ accelerating voltage using JEOL JSM 6610-LV (Figs 5, 6) and JEOL JSM-6390 (Figs 7, 8) scanning electron microscopes. The description of spore ornamentation is in accordance with Denchev et al. (2013). The height of the warts is measured in SEM. The description given below is based entirely on the specimens examined. The map was generated with SimpleMappr (Shorthouse 2010).

\section{Taxonomy}

Anthracoidea melanostachyae Denchev \& T. Denchev, Mycologia Balcanica 8: 153, 2011.

Figs 1-8

Sori in ovaries, scattered in the inflorescence, as subglobose, ovoid, broadly ellipsoidal or ellipsoidal, black, hard bodies, 2.2-3.0 mm long, when young covered by a thin, grayish membrane, later becoming exposed; spore mass of the mature sori powdery on the surface. Spores flattened, in plane view irregular, broadly elliptical or subpolygonal in outline, sometimes with protuberances, in plane view (13-)14-20(-22) × 11-18, single spores may reach up to $23.5 \mu \mathrm{m}$ in length, in side view $10.5-14 \mu \mathrm{m}$ thick, medium reddish brown; wall unevenly thickened, 1.0-2.5(-3.0) $\mu \mathrm{m}$ thick, thickest at the angles and protuberances, often with $1-3$, usually weak internal swellings, light-refractive areas present; minutely to moderately verruculose, spore profile not affected or slightly affected. In SEM warts $0.15-0.4 \mu \mathrm{m}$ high, usually isolated, sometimes confluent, forming small groups. Spore germination unknown.

Specimens examined - On Carex melanostachya M. Bieb. ex Willd.: ARMENIA, ARARAT PROVINCE, NNE of Zangakatun, E of Gortun, 39 51'08-59" N, 4503'0741" E, alt. ca 1850-2000 m, 14 Jun 2009, leg. K. Kugler \& E. Vitek, no. 09-0903 (W 2010-0005354; host plant determined by J. Koopman \& H. Więcław); VAYOTS DZOR PROVINCE, between the villages of Karaglukh and Shatin, near the creek, 14 Jun 1957, leg. E.T. Gabrielyan et al., s.n. (W 2006-0007601; host plant determined by T. Egorova); VAYOTS DZOR PROVINCE, near Herher (Gerger), 39 $47^{\prime} 09^{\prime \prime} \mathrm{N}, 45^{\circ} 32^{\prime} 15^{\prime \prime} \mathrm{E}$, alt. ca $1780 \mathrm{~m}$, 24 Jun 2005, leg. A. Herrero et al., no. 2783, Iter Armeniacum, VI-VII2005 (W 2007-0018593; host plant determined by M. Luceño); AZERBAIJAN, LERIK DISTRICT, 10 Jun 1938, leg. A.A. Grossheim, s.n. (LE, s.n.); IRAN, MAZANDARAN PROVINCE, Alborz Mts (Elburz Mts), Nezva Kuh area, near Orim, 3559' N, $53^{\circ} 11^{\prime}$ E, ca 2100 m, 5 Jul 1959, leg. P. Wendelbo (SOMF 29194 - holotype; host plant revised 


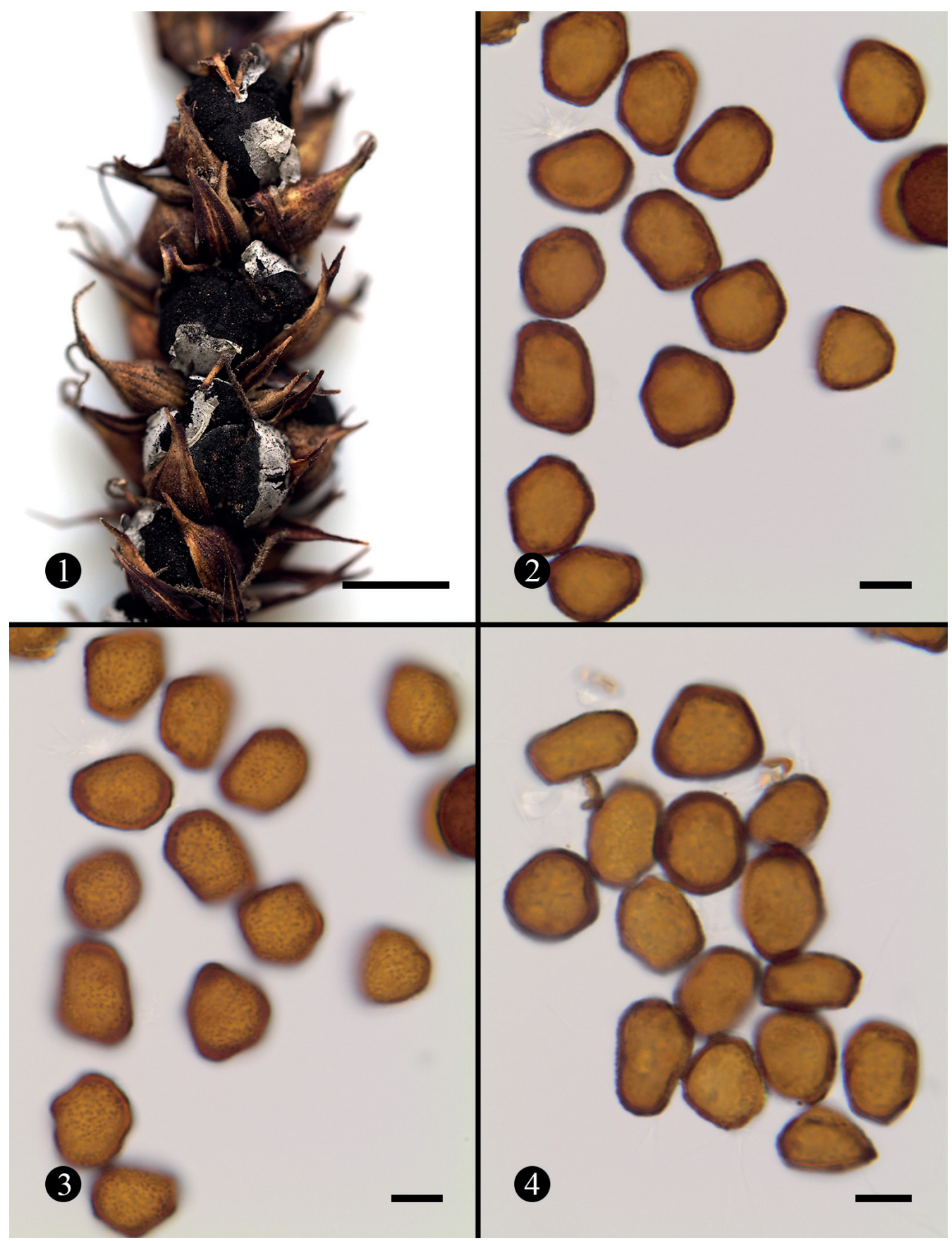

Figs 1-3. Anthracoidea melanostachyae on Carex melanostachya. 1. Habit (W 2007-0018593). 2, 3. Spores in LM (in median and surface view, respectively; W 2007-0018593). Fig. 4. Anthracoidea melanostachyae on Carex songorica - spores in LM (E). Scale bars: $1=3 \mathrm{~mm}$, $2-4=10 \mu \mathrm{m}$ 
by I. Kukkonen); GOLESTAN PROVINCE, Gorgan (Mohammad Reza Shah National Park), in quercetis (Q. castaneifolia) apertis ad cascades E Tang-e Gol., alt. ca $750 \mathrm{~m}, 4$ Jun 1975, leg. K.H. Rechinger, no. 52637, Iter Iranicum IX, 1975 (W 1976-0005986; host plant determined by I. Kukkonen); TAJIKISTAN, KHATLON PROVINCE, "Kulyabskaya Oblast, Leningrad Rayon", June 1980, leg. V.A. Mel'nik (as A. subinclusa, SOMF 16 377).

On Carex songorica Kar. \& Kir.: TAJIKISTAN, southern slopes of the Gissar (Hissar) Range, the watershed between Varzob River and Lyuchob River, 21 Jul 1938, leg. E. Varivtseva (E, s.n.).

Literature records (specimens not seen) - On Carex melanostachya: IRAN, EAST AZERBAIJAN PROVINCE, Kalibar to Khodaafarin, Govar village (IRAN 11967 F); TEHRAN PROVINCE, Firuz-Kuh city to Ghaemshahr city, Gaduk (IRAN 11362 F); GOLESTAN PROVINCE, Gorgan city, Golestan National Park, Tange Gol, SarCheshmeh, alt. 670-730 m (H.U.V. 20094, IRAN 83233 F); GOLESTAN PROVINCE, Azadshahr city (IRAN 11645 F) (Vánky \& Abbasi 2013).

Distribution: on Cyperaceae: Carex-subgen. Carex, sect. Tumidae: Carex melanostachya and C. songorica, Asia (Armenia, Azerbaijan, Iran, and Tajikistan) (Fig. 9).

Comments - Carex songorica is a new host plant of Anthracoidea melanostachyae.

Morphometric variability of spores of $A$. melanostachyae is presented in Table 1.

Table 1. Morphometric variability of spores of Anthracoidea melanostachyae

\begin{tabular}{lcccc}
\hline Host plant, country, specimen & Length & Width & M $\pm 1 \sigma$ & n \\
\hline On Carex melanostachya & & & & \\
Armenia (W 2006-07601) & $14.5-21.0$ & $13.0-18.0$ & $17.9 \pm 1.4 \times 15.6 \pm 1.3$ & 50 \\
Armenia (W 2007-18593) & $14.5-21.0$ & $12.5-17.0$ & $17.2 \pm 1.5 \times 14.6 \pm 1.2$ & 50 \\
Azerbaijan (LE, s.n.) & $14.0-21.5$ & $11.5-18.0$ & $17.8 \pm 1.7 \times 14.8 \pm 1.6$ & 50 \\
Iran (SOMF 29 194, holotype) & $13.0-22.0$ & $11.0-17.5$ & $16.7 \pm 1.7 \times 14.0 \pm 1.3$ & 250 \\
Iran (W 1976-05986) & $14.0-21.5$ & $12.0-18.0$ & $17.2 \pm 2.1 \times 14.4 \pm 1.3$ & 50 \\
Tajikistan (SOMF 16 377) & $14.0-23.5$ & $11.0-18.0$ & $18.7 \pm 1.9 \times 15.3 \pm 1.4$ & 200 \\
& & & & \\
On Carex songorica & & & & \\
Tajikistan (E, s.n.) & $14.0-22.0$ & $12.0-16.5$ & $17.6 \pm 2.2 \times 14.4 \pm 1.1$ & 50 \\
\hline
\end{tabular}

On members of Carex sect. Tumidae and C. sect. Paludosae s. str. (Carex acutiformis Ehrh.) five species of Anthracoidea are known: A. americana (Nannf. \& B. Lindeb.) Kukkonen, $A$. angulata (Syd.) Boidol \& Poelt, A. intercedens Nannf., A. songorica Vánky, and $A$. subinclusa (Körn.) Bref. Anthracoidea americana, A. intercedens, and $A$. subinclusa possess coarsely verrucose spore walls with large, irregular, apically flattened and slightly 


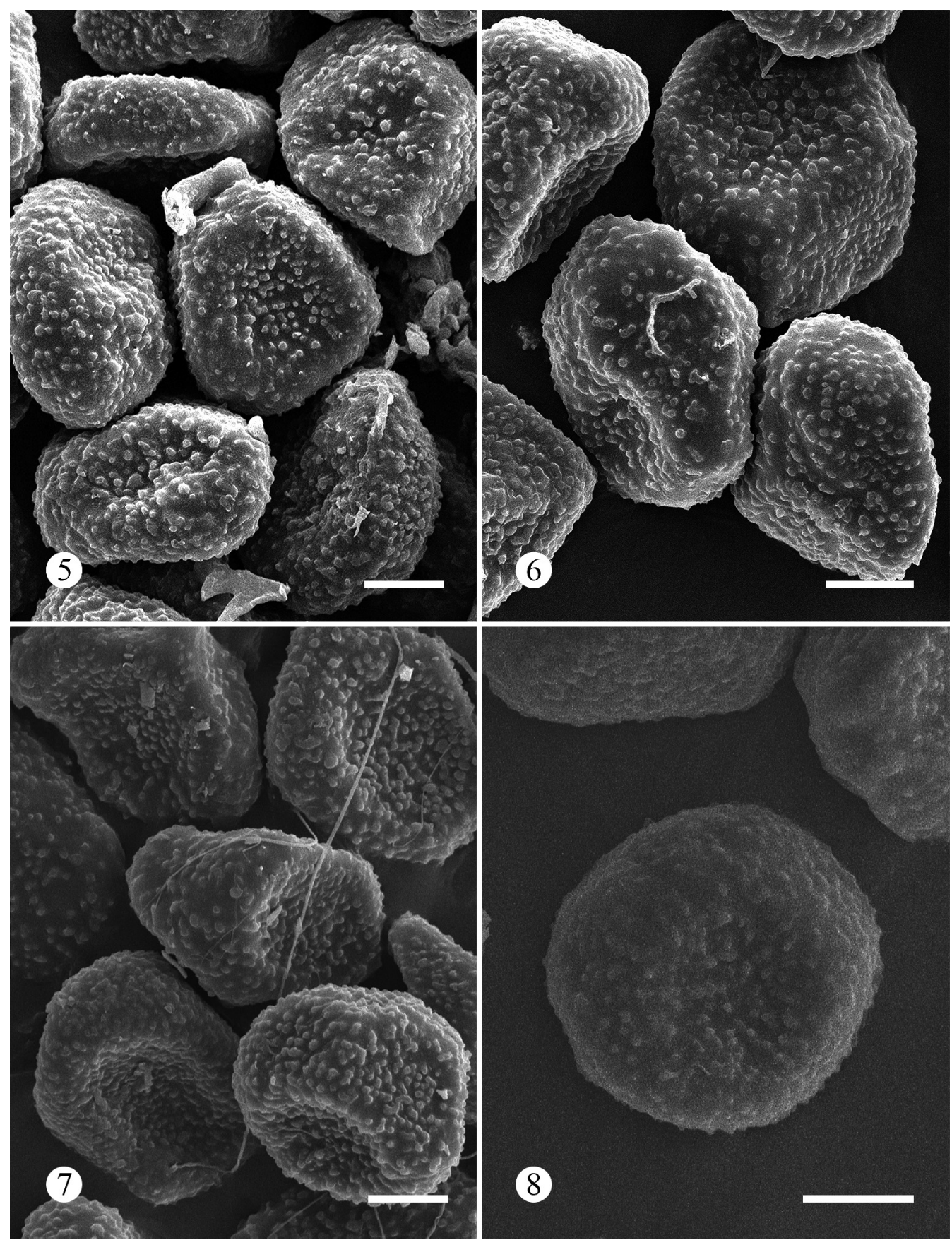

Figs 5, 6. Spores of Anthracoidea melanostachyae on Carex melanostachya in SEM (W 20060007601 \& W 2007-0018593, respectively). Fig. 7. Spores of Anthracoidea melanostachyae on Carex songorica in SEM (E). Fig. 8. Spores of Anthracoidea melanostachyae on Carex melanostachya in SEM (holotype). Scale bars $=5 \mu \mathrm{m}$ 


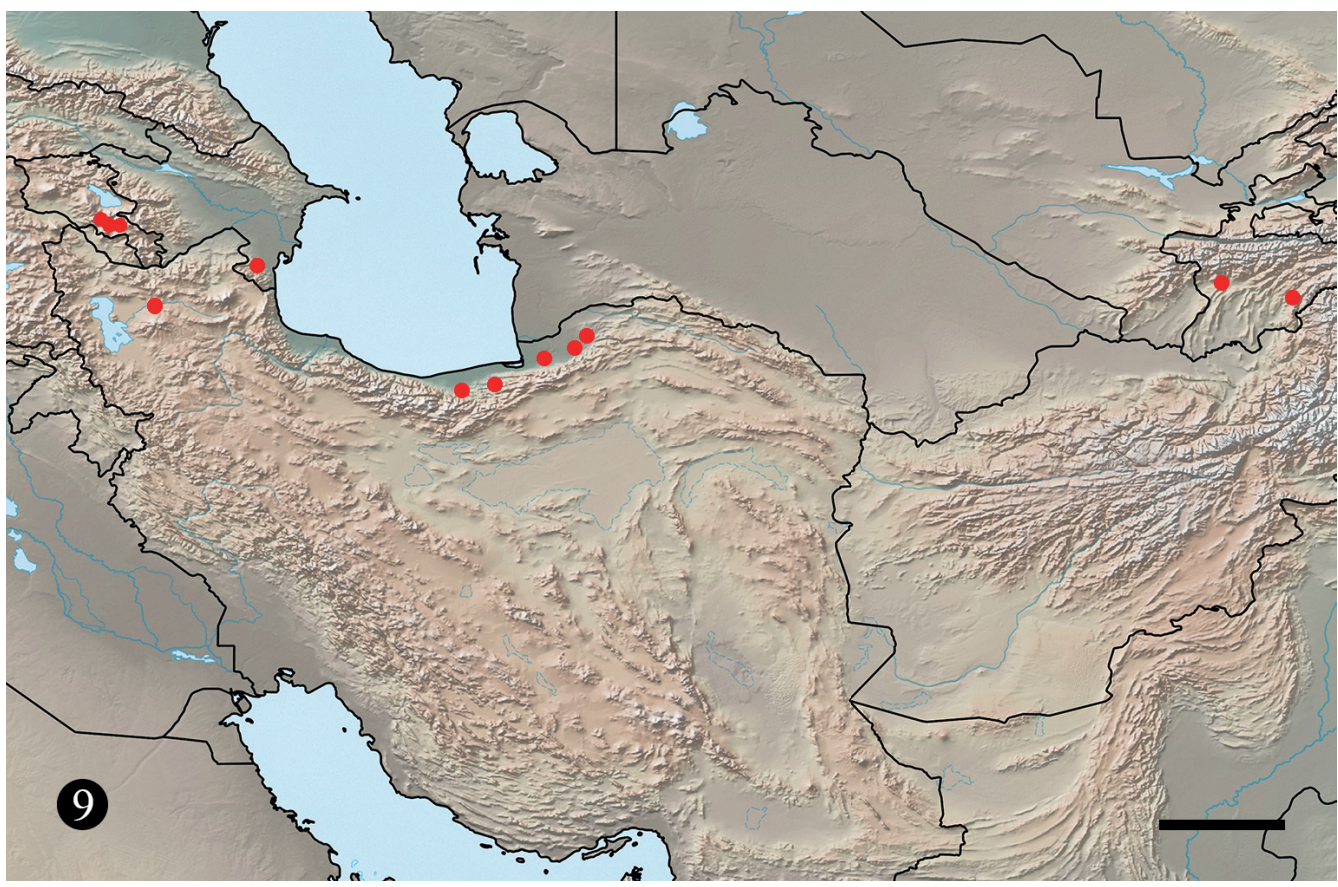

Fig. 9. Geographic distribution of Anthracoidea melanostachyae (generated with SimpleMappr, Shorthouse 2010). Scale bar $=300 \mathrm{~km}$

enlarged projections, higher than $0.5 \mu \mathrm{m}$ (Kukkonen 1964; Nannfeldt 1979; Denchev \& Minter 2011; Vánky 2011; Denchev et al. 2013). Anthracoidea melanostachyae differs from these three species in having minutely to moderately verruculose spores with warts up to $0.4 \mu \mathrm{m}$ high.

The spores of $A$. angulata are angular to very irregular, mostly with one to several conspicuous protuberances, 16-26(-28) $\mu \mathrm{m}$ long (with a range of the mean values of the spore length of 19-21 $\mu \mathrm{m})$, with a very unevenly thickened wall (1.5-5 $\mu \mathrm{m}$ thick), thickest at the angles and protuberances (Nannfeldt 1979; Vánky 2011). Anthracoidea melanostachyae differs from $A$. angulata by having more regular and smaller spores with thinner walls, and lacking conspicuous protuberances (Denchev \& Denchev 2011).

Anthracoidea melanostachyae differs from $A$. songorica on Carex songorica (known from Iran) by having smaller spores - (13-)14-20(-22) $\mu \mathrm{m}$ long, single spores up to $23.5 \mu \mathrm{m}$ in length, versus 19-27(-30) $\mu \mathrm{m}$ long for A. songorica (Vánky \& Abbasi 2012, 2013).

Acknowledgements. We are grateful to the directors and curators of the herbaria of the Natural History Museum Vienna (W), the Royal Botanic Garden Edinburgh (E), and the Komarov Botanical Institute, Saint Petersburg (LE) for the access to the collections and/or loan of specimens. This research received support (grant no. AT-TAF-5938 to T.T. Denchev 
\& C.M. Denchev) from the SYNTHESYS Project http://www.synthesys.info/, financed by the European Community Research Infrastructure Action under the FP7 "Capacities" Program. The assistance of Dr. Dan Topa (Central Research Laboratories, Natural History Museum Vienna) in SEM imaging is kindly acknowledged.

\section{References}

Denchev, C.M. \& Denchev, T.T. 2011. Anthracoidea melanostachyae, sp. nov. (Anthracoideaceae). - Mycologia Balcanica 8: 153-155.

Denchev, C.M. \& Minter, D.W. 2011. Anthracoidea intercedens. IMI Descriptions of Fungi and Bacteria. No. 1862. CAB International, Egham.

Denchev, T.T., Denchev, C.M., Michikawa, M. \& Kakishima, M. 2013. The genus Anthracoidea (Anthracoideaceae) in Japan and some adjacent regions. - Mycobiota 2: 1-125. http://dx.doi. org/10.12664/mycobiota.2013.02.01

Kukkonen, I. 1964. Taxonomic studies on the species of the section Echinosporae of Anthracoidea. - Annales Botanici Fennici 1: 161-177.

Nannfeldt, J.A. 1979. Anthracoidea (Ustilaginales) on Nordic Cyperaceae-Caricoideae, a concluding synopsis. - Symbolae Botanicae Upsalienses 22(3): 1-41.

Shorthouse, D.P. 2010. SimpleMappr, an online tool to produce publication-quality point maps. Available from: http://www.simplemappr.net (accessed 4 March 2016).

Vánky, K. 2011 ['2012']. Smut fungi of the world. APS Press, St. Paul, Minnesota, USA.

Vánky, K. \& Abbasi, M. 2012['2011']. Anthracoidea songorica sp. nov. on Carex songorica from Iran. Rostaniha 12: 181-185.

Vánky, K. \& Abbasi, M. 2013. Smut fungi of Iran. - Mycosphere 4: 363-454. http://dx.doi.org/10.5943/ mycosphere/4/3/2 